\title{
INFLUENCE OF THE PRINT LAYER HEIGHT IN FDM TECHNOLOGY ON THE ROLLING FORCE VALUE AND THE PRINT TIME
}

\author{
Wojciech Kiński ${ }^{\mathrm{a}^{*}}$, Paweł Pietkiewicz ${ }^{\mathrm{b}}$ \\ a Department of Mechanics and Basics of Machine Construction, University of Warmia and Mazury \\ in Olsztyn, e-mail: wojciech.kinski@uwm.edu.pl, ORCID 0000-0003-4973-7604 \\ b Department of Mechanics and Basics of Machine Construction, University of Warmia and Mazury \\ in Olsztyn, e-mail: papiet@uwm.edu.pl, ORCID0000-0002-6258-0384 \\ *Corresponding author:email: wojciech.kinski@uwm.edu.pl

\begin{tabular}{l}
\hline ARTICLE INFO \\
\hline Article history: \\
Received: September 2019 \\
Received in the revised form: \\
December 2019 \\
Accepted: December 2019 \\
\hline Key words: \\
3d printer, \\
FDM, \\
layer height, \\
breaking strength \\
\end{tabular}

\begin{abstract}
The paper presents a method and results of breaking of samples that undergo elongation, printed in the FDM (Fused Deposition Modelling) technology including various height of a layer. A method of description of the FDM print was described. A developed methodology of research was presented - it was analogous to the research on breaking steel samples. The aim of the research was investigation of the height of a single layer of print on the strength parameters of the produced object. The studies on samples printed with two types of filling were made. The obtained results were set and compared. Based on the research that was carried out, it may be concluded that the tensile strength of samples made in the FDM print technology is
\end{abstract} \\ proportional to the thickness of a single layer of print.
}

\section{Introduction}

A traditional method of production of plastic elements is based on the injection method of a specific dose of plastic to a specially prepared injection form. Incremental technologies are more often used for low-volume production or prototyping. A manner of production of objects by means of additive methods consists in building a real object layer by layer on the base on a three-dimensional model (Kiński and Pietkiewicz, 2017). Due to the price of devices and exploitation models, the most popular 3D printing technology is FDM (Fused Deposition Modelling). Devices working in this technology have become more popular amongst amateurs and hobbyists.

Thanks to 3D printers, objects made be manufactured from various plastic materials and composites. Each material has various parameters, inter alia, tensile strength, bending strength, which a user applies when selects a suitable raw material in relation to the future designation of the printed model. In incremental methods, a direction of placing the material, height of the model layer which are translated into various strength properties in various layers, are of importance (Szczesiak et al., 2018). Strength of models is also influenced by 
such parameters as the type and degree of model filling, temperature of the printing head or the speed of printing (Kiński et al., 2017).

Incremental technologies have been developing for ca. 30 years (practically for 15 years because they were patented before). Therefore, in literature there is a scarcity of publications treating of the impact of particular parameters on the quality of produced objects. The user who manufactures models has no knowledge to what extent a particular parameter translates into a ready product (printing time, visual quality, strength). The aim of this article is analysis of the impact of the layer height of the built model on the value of the breaking force and time spent on its production. The studies were performed for two levels of the density of a filling.

\section{FDM technology}

This is one of the most popular methods of incremental production. This technology was invented in the 80's of the 20th century (Skowyra et al., 2015). It consists in building a real object by placing a melted plastic layer by layer bonding together previously placed layers (Nancharaiah et al., 2010). Material, the most often in the form of a cord rolled up on a spool or in the form of pellets, is conveyed to a pressing unit where in the head it is heated up to the melting temperature and then pressed through a nozzle. Figure 1 schematically presents a principle of the FDM technology performance.

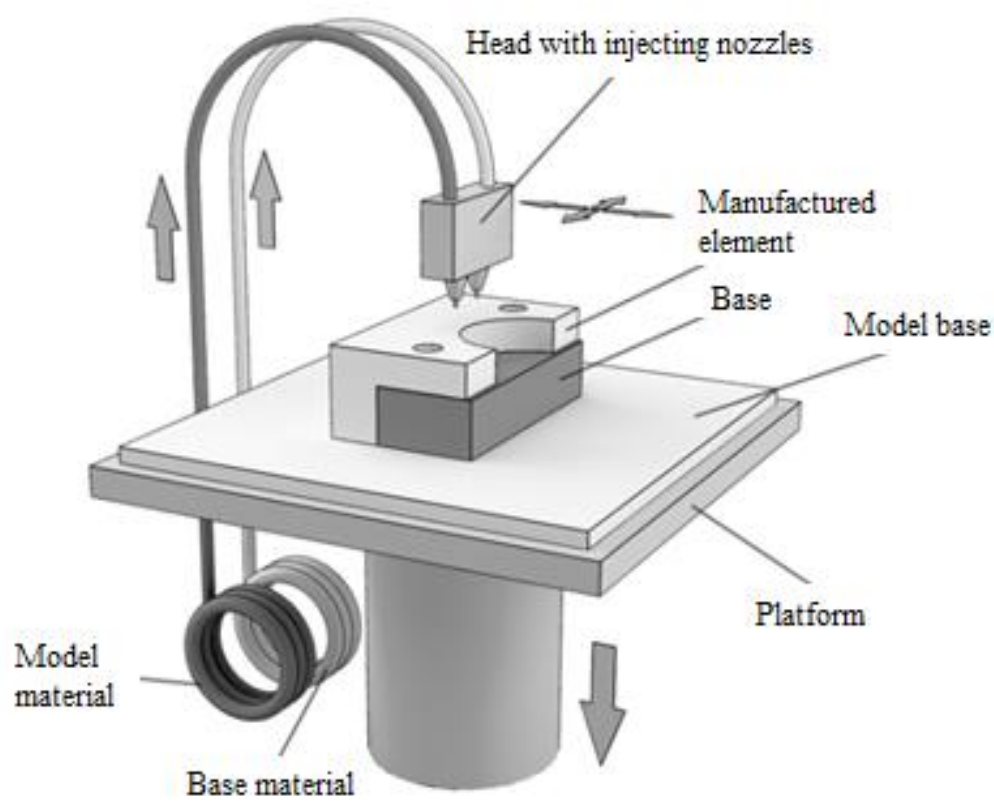

Figure 1. Principle of FDM technology performance (Kiński and Pietkiewicz, 2018) 
Influence of the print...

\section{Breaking force tests}

A tensile test method of plastic is described in the standard PN-EN ISO 527:1998, titled Plastic. Determination of mechanical properties at static expansion (Miazio, 2018). Due to the measurement scope of the strength machine where breaking tests were carried out, a model for tests was suitably modified and designed in SolidWorks program.

Figure 2 shows a view of a sample for testing. Table 1 includes its dimensions.

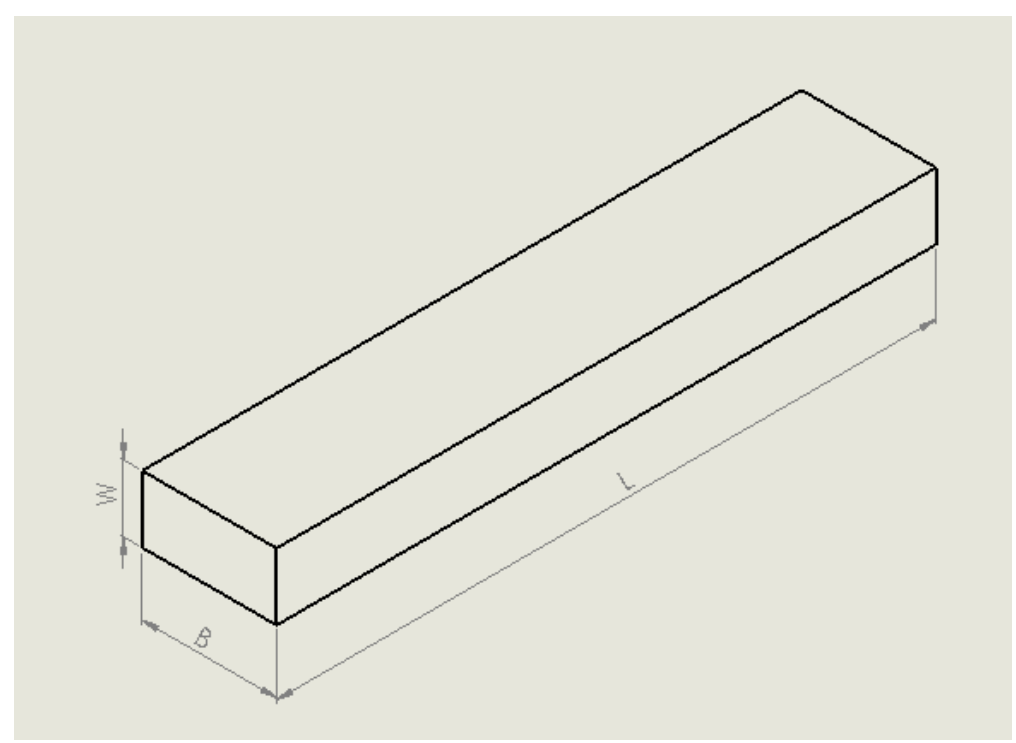

Figure 2. A sample for determination of the breaking force value [author's own study]

Table 1.

Dimensions of a sample

\begin{tabular}{lc}
\hline Dimensions of a matrix & Dimension \\
\hline L - length & $150 \mathrm{~mm}$ \\
B - width of matrix & $15 \mathrm{~mm}$ \\
W - height of matrix & $8 \mathrm{~mm}$ \\
\hline
\end{tabular}

A grid of the STL model is based on tetrahedral elements. Therefore, mapping of arches and rounded elements is somehow simplified (Hiller and Lipson, 2009). Executive file GCODE was generated in the commercial program Simplify 3D.

Samples were printed for the tests of the breaking force with the use of Graften One M2. Samples were manufactured of Verbatim PLA (Polyactyd) material. It is completely biodegradable plastic. Lactic acid is a basic building element (Nowak and Pająk, 2010). Table 2 includes parameters of printing of samples: 
Kiński Wojciech, Pietkiewicz Paweł

Table 2.

Parameters of printing

\begin{tabular}{lc}
\hline Name & Value \\
\hline Height of the first layer & $0.3 \mathrm{~mm}$ \\
Speed of printing & $50 \mathrm{~mm} \cdot \mathrm{s}^{-1}$ \\
Thickness of the model walls & $0.8 \mathrm{~mm}$ \\
Air supply that cools the print & $100 \%$ \\
Working platform temperature & $55^{\circ} \mathrm{C}$ \\
PLA headtemperature & $210^{\circ} \mathrm{C}$ \\
Headnozzlediameter & $0.4 \mathrm{~mm}$
\end{tabular}

Figure 3 presents a course of the breaking force for samples printed from PLA material with a cross filling with a varied degree of compaction at the height of the printing layer of $0.2 \mathrm{~mm}$ (Miazio, 2015).

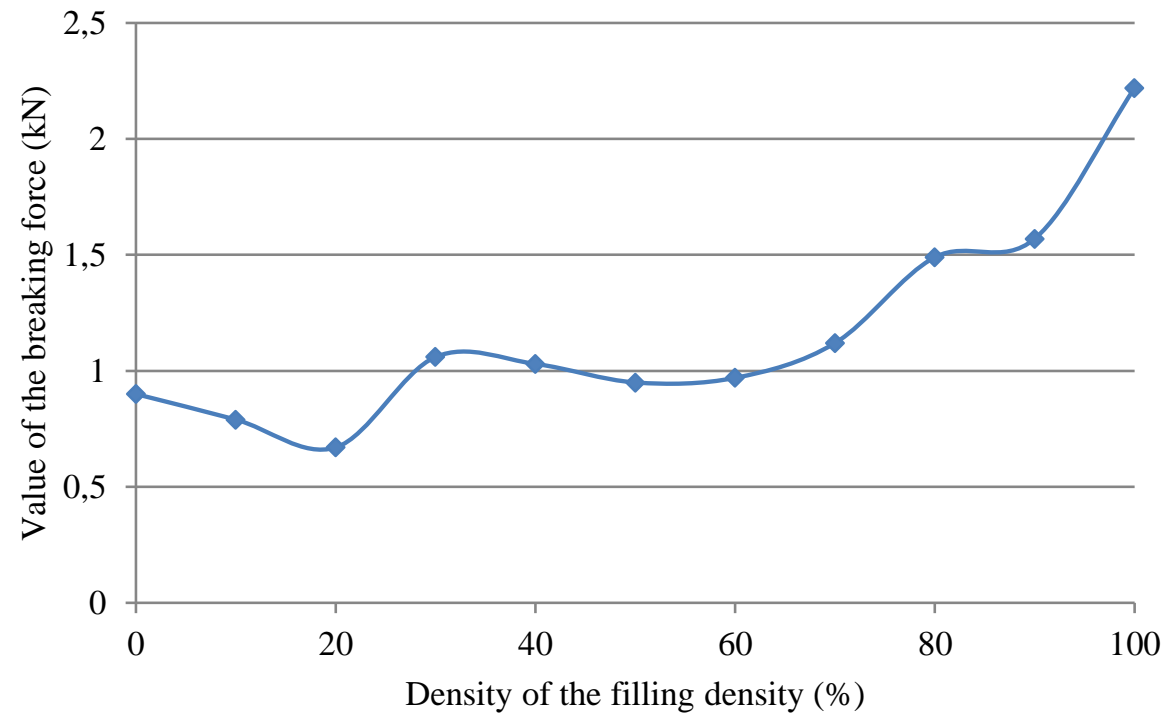

Figure 3. Results of research on the relation of the breaking force to the filling (Miazio, 2015)

Using the relation presented graphically in figure 1, where the impact of the compaction degree on the breaking force, a decision was taken to perform tests at two various values of the samples filling (50\% and $100 \%)$. 
Influence of the print...

Samples for strength tests were printed with the layer height within 0.1 to $0.3 \mathrm{~mm}$ with a step every $0.02 \mathrm{~mm}$. A cross filling in the form of a grid perpendicularto the model walls was applied.

Figure 4 shows a photo of a sample destroyed during a test.

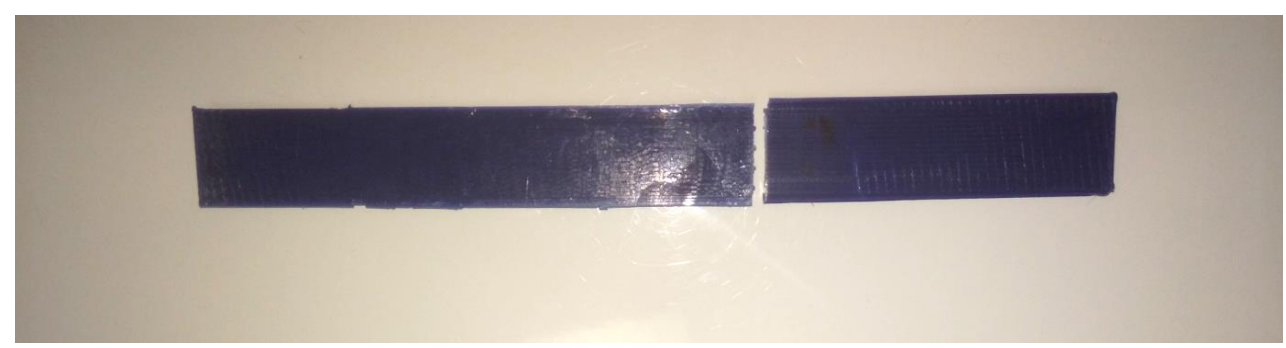

Figure 4. View of a sample after strength test (author's own study)

Due to a high repeatability and precision of 3D printer, each attempt to determine the value of the breaking force was performed three times. The provided results are average results.

Table 3.

List of average forces that break a sample

\begin{tabular}{lcccc}
\hline \multicolumn{5}{c}{ Degree of filling 50\% } \\
\hline $\begin{array}{l}\text { Height of } \\
\text { a layer }(\mathrm{mm})\end{array}$ & $\begin{array}{c}\text { Sample 1: } \\
\text { breakingforce }(\mathrm{kN})\end{array}$ & $\begin{array}{c}\text { Sample 2: } \\
\text { breakingforce }(\mathrm{kN})\end{array}$ & $\begin{array}{c}\text { Sample 3: } \\
\text { breakingforce }(\mathrm{kN})\end{array}$ & $\begin{array}{c}\text { Average values } \\
\text { of breaking force }(\mathrm{kN})\end{array}$ \\
\hline 0.10 & 1.25 & 1.30 & 1.20 & 1.25 \\
0.12 & 1.30 & 1.30 & 1.30 & 1.30 \\
0.14 & 1.40 & 1.35 & 1.35 & 1.37 \\
0.16 & 1.30 & 1.40 & 1.35 & 1.35 \\
0.18 & 1.50 & 1.45 & 1.40 & 1.45 \\
0.20 & 1.60 & 1.50 & 1.45 & 1.52 \\
0.22 & 1.70 & 1.75 & 1.75 & 1.73 \\
0.24 & 1.85 & 1.90 & 1.90 & 1.88 \\
0.26 & 2.05 & 2.00 & 2.00 & 2.02 \\
0.28 & 1.95 & 2.00 & 2.00 & 1.98 \\
0.30 & 2.25 & 2.20 & 2.25 & 2.23 \\
\hline
\end{tabular}


Kiński Wojciech, Pietkiewicz Paweł

\begin{tabular}{lcccc}
\hline $\begin{array}{l}\text { Height of } \\
\text { a layer }(\mathrm{mm})\end{array}$ & $\begin{array}{c}\text { Sample 1: } \\
\text { breakingforce }(\mathrm{kN})\end{array}$ & $\begin{array}{c}\text { Sample 2: } \\
\text { breakingforce }(\mathrm{kN})\end{array}$ & $\begin{array}{c}\text { Sample 3: } \\
\text { breakingforce }(\mathrm{kN})\end{array}$ & $\begin{array}{c}\text { Average values } \\
\text { of breaking force }(\mathrm{kN})\end{array}$ \\
\hline 0.10 & 4.45 & 4.55 & 4.60 & 4.53 \\
0.12 & 4.40 & 4.60 & 4.55 & 4.52 \\
0.14 & 4.50 & 4.70 & 4.70 & 4.63 \\
0.16 & 5.00 & 4.90 & 4.85 & 4.92 \\
0.18 & 5.10 & 5.00 & 5.15 & 5.08 \\
0.2 & 4.85 & 4.90 & 4.95 & 4.90 \\
0.22 & 4.90 & 4.95 & 4.90 & 4.92 \\
0.24 & 4.95 & 5.00 & 5.10 & 5.02 \\
0.26 & 5.00 & 4.95 & 5.10 & 5.02 \\
0.28 & 5.20 & 5.25 & 5.20 & 5.22 \\
0.30 & 5.45 & 5.30 & 5.40 & 5.38 \\
\hline
\end{tabular}

Table 4.

List of printing time of particular samples

\begin{tabular}{lcc}
\hline $\begin{array}{l}\text { Height of a layer } \\
(\mathrm{mm})\end{array}$ & $\begin{array}{c}\text { Printing time of a sample with } \\
\text { 50\% of filling (min) }\end{array}$ & $\begin{array}{c}\text { Printing time of a sample with } \\
\text { 100\% filling (min) }\end{array}$ \\
\hline 0.10 & 132 & 200 \\
0.12 & 113 & 167 \\
0.14 & 98 & 144 \\
0.16 & 88 & 126 \\
0.18 & 80 & 114 \\
0.20 & 74 & 103 \\
0.22 & 67 & 93 \\
0.24 & 64 & 86 \\
0.26 & 61 & 81 \\
0.28 & 57 & 76 \\
0.30 & 54 & 71 \\
\hline
\end{tabular}

A graph in figure 5 is a graphic interpretation of relations of average forces that break the tested samples to the height of layers at two degrees of filling. 


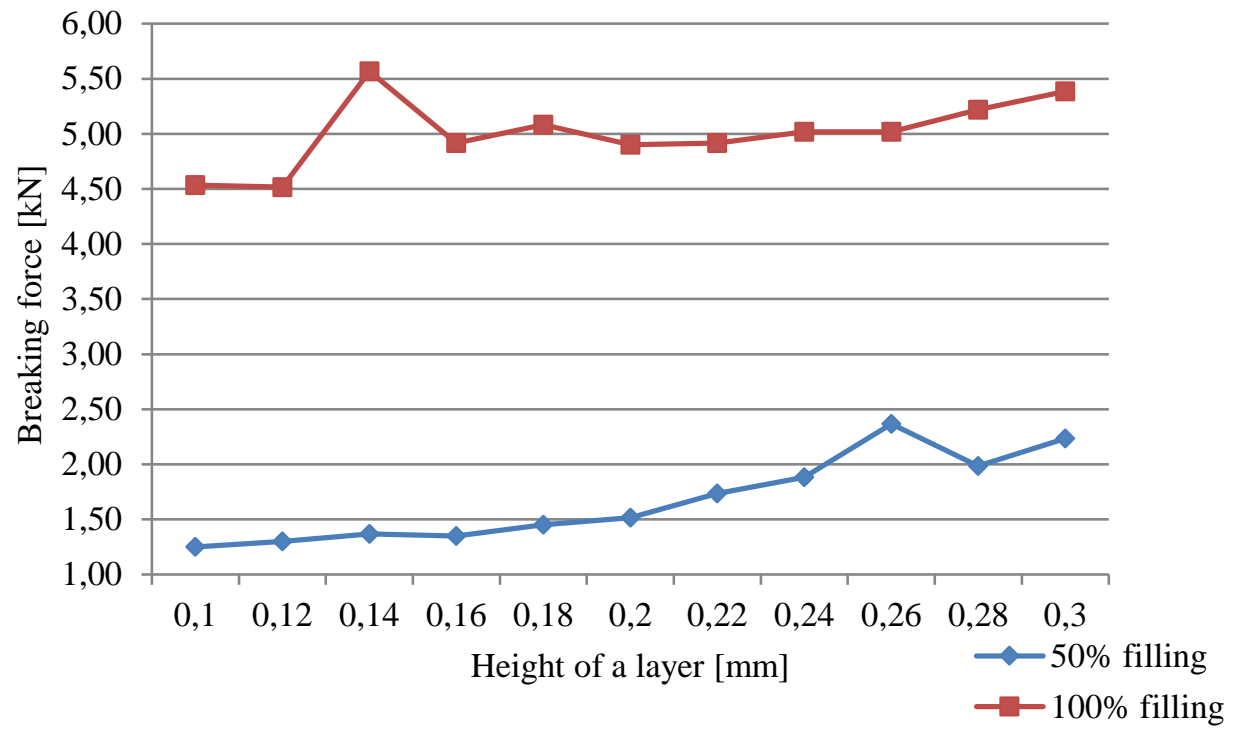

Figure 5. Average force that breaks a sample in relation to the height of the print layer (author's own study)

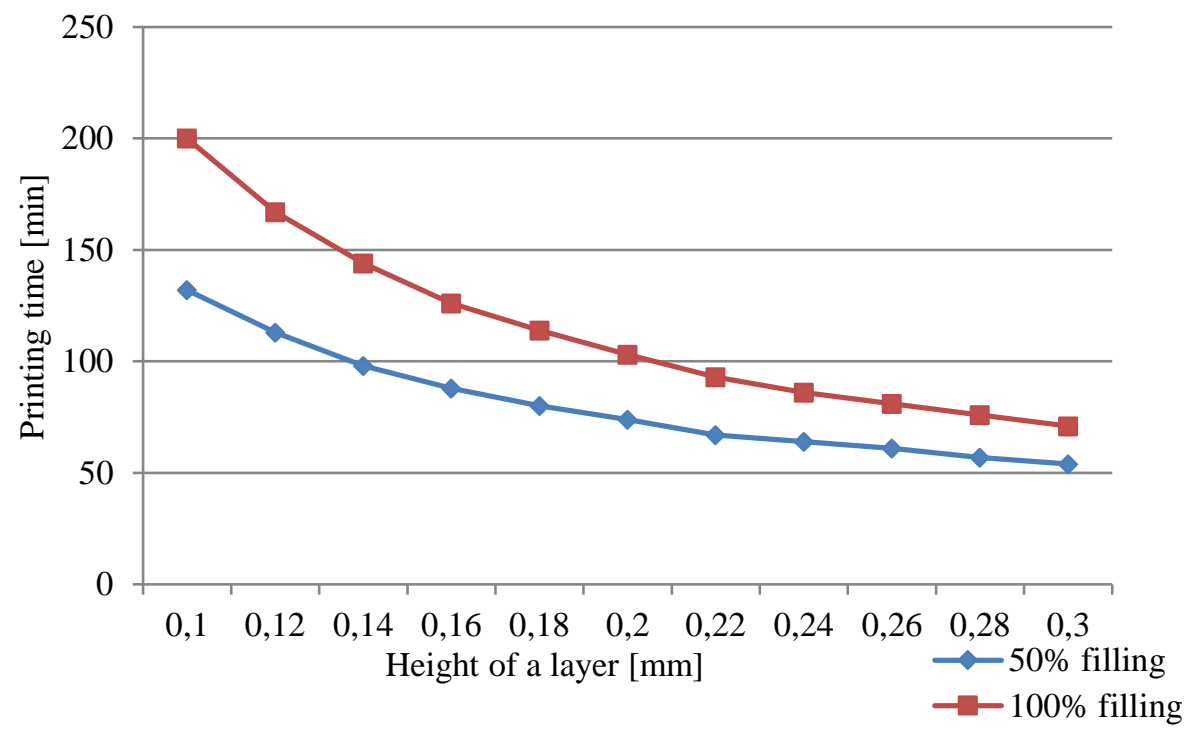

Figure 6. Relation of printing time to the layer height of the model (author's own study) 
In both cases of the filling degree of samples, one may observe the increase of the value of the breaking force along with the height of the single layer of printing. These relations approximately have a linear character.

Figure 6 shows a relation of the printing time to the applied height of a single layer. Along with the increase of the height of a single layer of plastic placed during printing, the time of the entire printing decreases, but it is visible that along with the increase of the layer thickness, the difference of the printing time decreases with different levels of filling.

\section{Conclusion}

Models made with the use of a 3D printer due to the layer construction (an anisotropic nature) have a different strength than objects made with a traditional injection method. However, by means of the programme that prepares a three-dimensional model for printing and innovative devices one may affect the strength parameters considerably through selection of relevant parameters (e.g. type and density of filling, model orientation on the working platform).

After the attempts that were made, one may notice that broken samples broke in the $2 / 3$ length of the sample. When analysing the results, one may conclude that the relation of the breaking force to the height of the layer is approximately linear.

Despite this observation, it should be concluded that the value of the breaking force of a sample with a 50\% degree of filing for the sample printed at the height of the layer of $0.1 \mathrm{~mm}$ is practically two times lower in comparison to the sample printed at the height of the layer of $0.3 \mathrm{~mm}$.

On the other hand, analogous comparison of the relation of the breaking force to the height of the layer in case of samples with $100 \%$ degree of filling enables to notice that it is approximately $20 \%$ higher than for the height of $0.1 \mathrm{~mm}$ in comparison to $0.3 \mathrm{~mm}$ samples. These observations lead to the conclusion that despite the course of variability of the breaking force that is similar to linear from the height of the print layer, these values are directly proportional.

Analysis of the printing time of samples for the studies on the breaking force value enables to notice that in case of samples with $50 \%$ degree of filling, at the change of the height of the layer of printing from $0.1 \mathrm{~mm}$ to $0.3 \mathrm{~mm}$, the increase of the breaking force value by $78 \%$ was obtained at the simultaneous $60 \%$ reduction of the printing time of a sample with the height of the layer. In case of $100 \%$ degree of filling the samples, the breaking force value for a $0.3 \mathrm{~mm}$ layer increased by $19 \%$ referred to the model printed with $0.1 \mathrm{~mm}$ layer. The printing time decreased on the other hand by $65 \%$.

The studies that were carried out are a part of the greater undertaking performed in the Department of Mechanics and Foundations of Machines Construction of the University of Warmia and Mazury in Olsztyn. It aims at building of some kind of a "choice grid" of the 3D print quality in the FDM technology. When constructing a model in the FDM technology, a user may choose between the printing time, desired strength properties and the quality of models. When printing an object with a considerable height of the layer we will obtain a model that stands out with a decisively shorter time of printing, better resistance to breaking but a deteriorated visual quality when referred to the model built from low layers and 
Influence of the print...

a considerably lower degree of mapping of model dimensions during printing. Presently, results of the research on this subject are being developed.

\section{References}

Hiller, J., Lipson, H. (2009). STL 2.0: A proposal for a universal multi-material additive manufacturing file format. Proceeding of the Solid Freeform Fabrication Symposium, Austin, TX, 266-278.

Kiński, W., Pietkiewicz, P. (2017). Główne parametry eksploatacyjne wpływające na jakość wydruku w technologii FDM. Przeglad mechaniczny,6, 54-56.

Kiński, W., Pietkiewicz, P., Nalepa, K., Miąskowski, W. (2017). Porównanie wytrzymałości na rozciąganie próbek kompozytowych wydrukowanych w technologii FDM. Mechanik, 7, 615-617.

Kiński, W., Pietkiewicz, P. (2018). Koncepcja systemu podawania materiału w drukarkach 3D wykorzystującego zużyty materiał w technologii FDM. Mechanik, 7, 543-545.

Miazio, Ł. (2015). Badanie wytrzymałości na rozciąganie próbek wydrukowanych w technologii FDM z różną gęstością wypełnienia. Mechanik, 7, 533-538.

Miazio, Ł. (2018). Badanie wytrzymałości na zginanie próbek wydrukowanych metodą FDM z wypełnieniem heksagonalnym, koncentrycznym i trójkątnym. Mechanik, 7, 546-548.

Nancharaiah, T., Raju, D.R., Raju, V.R. (2010). An experimental investigation on surface quality and dimensional accuracy of FDM components. International Journal on Emerging Technologies, 1, 106-111.

Nowak, B., Pajak, J. (2010). Biodegradacja polilaktydu (PLA). Archiwum Gospodarki Odpadami i Ochrony Srodowiska, 2, 1-10.

Skowyra, J., Pietrzak, K., Mohamed, A. (2015). Fabrication of extended-release patient-tailored prednisolone tablets via fused deposition modelling (FDM) 3D printing. European Journal of Pharmaceutical Sciences, 68, 11-17.

Szczesiak, R., Kowalik, M., Cader, M., Pyrzanowski, P. (2018). Parametryczny model numeryczny do predykcji właściwości mechanicznych struktur wytwarzanych w technologii FDM z materiałów polimerowych. Polimery, 9, 626-632.

\section{WPLYW WYSOKOŚCI WARSTWY DRUKU W TECHNOLOGII FDM NA WARTOŚĆ SILY ZRYWAJĄCEJ ORAZ CZAS WYDRUKU}

Streszczenie. W artykule przedstawiono metodykę oraz wyniki zrywania próbek podlegających rozciąganiu, wydrukowanych w technologii FDM (FusedDeposition Modeling) z uwzględnieniem różnej wysokości warstwy. Opisano metodę wydruku FDM. Przedstawiono opracowaną metodykę badań - analogiczną do badań zrywania próbek stalowych. Celem badań było zbadanie wpływu wysokości pojedynczej warstwy wydruku na parametry wytrzymałościowe wytwarzanego obiektu. Wykonano badania próbek wydrukowanych przy dwóch rodzajach wypełnienia. Otrzymane wyniki zostały zestawione i porównane. Na podstawie przeprowadzonych badań można stwierdzić, że wytrzymałość na rozciąganie próbek wykonanych w technologii druku FDM jest proporcjonalna do grubości pojedynczej warstwy wydruku.

Słowa kluczowe: druk 3D, FDM, wysokość warstwy, siła zrywająca 